\title{
Impact of Microcredit on Living Standard of Dairy Entrepreneurs: Special Focus on Oddusuddan DS Division in Mullaitivu District
}

\author{
Saseela Balagobei \\ Department of Financial Management \\ Faculty of Management Studies \& Commerce \\ University of Jaffna, Sri Lanka \\ E-mail: saseelab@univ.jfn.ac.lk \\ Sankeetha Aravinthakumar \\ Department of Financial Management \\ Faculty of Management Studies \& Commerce \\ University of Jaffna, Sri Lanka
}

\begin{abstract}
Microcredit is part of micro finance, which provides a wider range of financial services for low income people. Micro credit serves as a vital role for Living standard of poor people in the developing countries as well as in Sri Lanka. In this Study Oddusuddan DS division in Mullaitivu district was selected as research area. After the 30 years conflict situation most people in the Oddusuddan area in Mullaitivu district are subordinate to the poverty line, because most of the displaced people who are female other than male staying here. Women lost their male relatives in struggle, and forced to take a responsibility of their family in order to look after their children, aged parents and their male relatives. Micro credit helps the poor people particularly women in effective ways in order to create income generating activities. The prime objective of this study is to investigate the impact of Microcredit on living standard of dairy entrepreneurs in Oddusuddan DS division in Mullaitivu District. In the rural areas of Mullaitivu, Oddusuddan Divisional Secretariat Divisions IOO dairy entrepreneurs were selected as the sample size of population. The selected entrepreneurs who have received loan from samurdhi bank for dairy farming activities in Oddusuddan DS Division. Primary data were used for gathering information and quantitative analysis was carried out to find out the results. In the quantitative analysis the correlation and regression methods were employed to examine the hypotheses by using SPSS. The result of this study concluded that there is a positive impact of samurdhi micro credit on living standard of dairy entrepreneurs in Oddusuddan DS Division. In addition to this, using micro credit facilities create more job opportunities and variety of economic activities and improve household education, income, saving and heath condition of the people. The study recommends that micro credit institution should consider improve the living standard of dairy entrepreneurs through increase the loan amount with lower interest rate.
\end{abstract}

Keywords: Microcredit, Dairy Entrepreneurs, Living Standard.

\section{Introduction}

Microcredit plays a vital role in significant innovations in development policy of the past twenty-five years. Microfinance is not a new concept; it comes from the development of Grameen bank concept introduced by Mohammad Yunus in Bangladesh. But it traced back to 1906 in Latin America. Thus, there was evidence for in the social banking, group-based lending, self-help group concepts, etc. Normally rural financial market can identify as formal financial market and informal financial market which act as financial intermediaries. In developing country as a Sri Lanka formal financial institution doesn't serve financial services to the rural sector efficiently. Moreover, Low income people cannot be satisfied regarding formal financial institution's lending procedures. Because they haven't any fixed income way or any collateral to obtain financial services. So, the more people obtain the loans from informal financial institutions or informal money providers as low-income people are facing poorer situation and also, they save their funds in informal channels. So, they don't provide any guarantee for that savings. The microfinance activities have given a financial solution for that kind of people.

Further microfinance comes with the main objective of providing financial services to the poor segments of the society, contributes its role in the form of financial development with a primary focus on enhancing the living standard through poverty alleviation. In the last two decades, there are several modifications in the microfinance sector such as, introduction of micro insurance, diversification of products, provide instructions and several types of collateral free flexible loan as the capacity of the borrowers.

Microcredit is part of micro finance, which provides a wider range of financial services, especially savings accounts, to the poor. Many traditional banks subsequently introduced micro credit despite initial misgivings. The United Nations declared 2005 as the international year of micro credit. As of 2012 microcredit is widely used in developing countries and is presented as having enormous potential as a tool that can be helpful to possibly reduce feminization of poverty in developing countries. 
It is the extension of very small loans (microloans) to impoverished borrowers who typically lack collateral, steady employment, and a verifiable credit history. The microcredit movement aims to extend small amounts of capital to poor borrowers throughout the world, typically to facilitate income-generating self-employment activities. Thus, it has popularized creative, perhaps ingenious, lending techniques (Ahlin \& Jing, 2008). On other hand improvement in living standard of low-income society in developing countries is achieved by improving health, education, income level, physical asset ownership and other living standards. This phenomenon diminishes poverty and foundations to achieve poverty alleviation objective gradually. Poverty can identify as where people cannot meet their basic needs for survival, such as food, water, clothing, shelter, sanitation, education and health care.

As per Barr (2005) in the global situation, there are about three billion people, half of the world's population, living on the income of less than two dollars a day. Among these poor communities, one child in five does not live to see his or her fifth birthday. To avoid this situation as early mentioned micro credit is the best mechanism for improving the living standard of the poor people.

Poverty is a mainly rural phenomenon in Sri Lanka and four sectors of poverty can be identified in Sri Lankan society, such as rural, coastal, urban and state sector. Low level of living condition also affects the government policies and their development programs.

Currently, there is a wide range of institutions that are involved in providing microfinance services to low income groups. These include Co-operative Societies (e.g. TCCSs), hundreds of local and international Non-governmental Organizations (NGOs), commercial banks (both state-owned and private) and development banks such as the Regional Development Banks (RDBs) and the Sanasa Development Bank (SDB). In addition, the Government's Samurdhi Savings and Credit Scheme established in 1996 is presently one of the largest social mobilization programmes in Sri Lanka. It was the national program for increase living standard of the low-income people under government supervision. It was a valuable certificate to low income people when engage with financial such poverty alleviation programs and when obtaining financial facilities for that program.

Mullaitivu is considered one of the more prosperous districts in comparison with other districts in the North. However, poverty raised by inequalities in income, employment, infrastructure, health and educational facilities is trickled within the post-war situation. Prior to the explosion of the civil conflict, Mullaitivu enjoyed a healthy economy. The foreign aids are used to develop the local economy in Sri Lanka most probably in the war affected areas specifically in Mullaitivu because most of the displaced people who are female other than male staying here. This study deals with the empowerment of rural dairy entrepreneurs through the micro credit activities and the challenges and scenarios under the post war development in selected rural areas in Mullaitivu District. Therefore, this study id endeavour to investigate the extent to which these micro credit activities of Sri Lanka lead to enhance the living standard of poor people in Oddusuddan DS Division.

\section{Problem of the Statement}

It is accepted from the researches that the microcredit is an important tool to enhance the entrepreneurship development in the developing countries as well as in Sri Lanka. In the post war context, it has been realized from the past experiences in Sri Lanka. However, there are some challenges and difficulties facing by entrepreneurs for their sustainable development.

The most people in the Oddusuddan area in Mullaitivu district are subordinate to the poverty line. The economy of the district mainly depends on agriculture and fishing. The agriculture sector is the main income generating source in this district and the livestock is an important sector of the people of Oddusuddan division. Livestock as a high priority sector for future growth, investment and poverty alleviation. Livestock farming is traditional activity of the Oddusuddan people. Livestock provides not only the supplementary income but also a main source of animal protein.

However, people faced various tribulations on livestock framing in this area such as death of the cattle due to the war context and continuous climate changes, due to the high temperature and urbanization the water has been drained and grazing lands have been destroyed thus maintenance cost of the livestock increased.

As well higher cost of cattle feed and increase in the cost of labour have an impact on the development of dairy farming. So, the people need capital to manage the maintenance cost and purchase the new cattle. After the resettlement people faced lot of hardship to mobilize capital to start and continue to run the self-employment activities. The Micro credit becomes a major tool for development of entrepreneurs in Sri Lanka.

Micro finance Institutions as part of their core business provide credit facilities to the entrepreneurs. In addition to the financial services, it provides social intermediations, enterprise development and social services like business and skill training, financial and business management and capacity building to improve their capacity on managing the resources granted them to facilitate the self-employment activities. Further, the numbers of micro finance institutions in Mullaitivu District growing rapidly. However, their wide existence does not match with the extent of reduction in the major challenges that affect the growth of self-employable activities in Mullaitivu. So, there is a way to mobilize such capital through the micro credit.

However, the most of the researches have been done regarding the women empowerment, entrepreneurship development and micro Credit programmes in worldwide, it is very little bit in Sri Lanka especially in Mullaitivu District. This study attempts to fill this research gap and raising the following research question as a research problem:

How does micro credit impact on living standard of dairy entrepreneurs (special focus on Oddusuddan DS Division in Mullaitivu District)? 


\section{Objective of the Research}

- The prime objective of this research is to investigate the impact of microcredit on living standard of dairy entrepreneurs in Oddusuddan DS division in Mullaitivu District.

\section{Literature Review and Hypotheses Development}

Kaluarachchi \& Jahfer (20I4) investigated micro finance and poverty alleviation in Sri Lanka using selected microfinance beneficiaries from Polonnaruwa District. Attention was mainly given to identify the contribution of microfinance for the poverty alleviation. Accordingly, loan amount, repayment ability, accessibility of getting loan and interest rate were identified as significant factors that lead to reduce poverty among people. Finding further indicated that microfinance initiatives of the area had significantly uplifted lives of the poor.

Jayasuriya (2007) investigated the impact of microfinance on poverty alleviation in Sri Lanka through the impact of Samurdhi saving and credit programme for uplifting living condition of the poor. The study collected data from five Samurdhi bank and 20 Samurdhi holders randomly from Kegalle District. Findings of the study indicated that Samurdhi credit scheme helps poor people to sustaining their current survives.

Further in Sri Lankan context the microfinance and livelihood development in poor coastal communities in Eastern Sri Lanka was examined by Thilepan \& Thiruchelvam (20II). This study investigated the effectiveness of microfinance support for coastal communities' livelihood development in Trincomalee District. The study found that there is a significant impact of microfinance on people's income and saving level.

Abel, Grace, Willie (2014) investigated factors influencing poverty alleviation amongst microfinance adopting households in Zambia. Findings specified that majority of respondents could improve their well-being through microfinance initiatives. A study done by Awele Oguejiofor \& Unachukwu (20I4) identified interest rate, small size of loans, short loan repayment cycles, and very frequent group meeting as factors that affect successful graduation of microfinance clients from microfinance programs in Philippines.

The impacts of microfinance institutions on eradication of poverty in Meru South Sub County were examined by Makunyi (2017). The target population for this study comprised of all beneficiary households of Microfinance Institutions (MFIs) in Meru South Sub Country and sample was 30\% of the target population. Findings of the study highlighted microfinance institutions as a very strong tool in poverty alleviation process at household level. In this process micro credit empowers the poor, enables them to cope with and overcome many of problems that they face. Further, microfinance loans were found to have led to establishment and expansion of businesses, acquisition of shelter, education, access to health care and opening up of opportunities for the poor to improve their living standard.

Idowu \& Salami (20II) also examined impact of microfinance bank has on standard of living of hairdressers in Oyo State. A total of 49 hairdressers who registered with Ogbomosho North LGA were used as study sample. The findings of the study indicated that there is a significant relationship between Microfinance bank efforts and standard of living of hairdressers in Ogbomoso North LGA. Similarly, a positive impact of microfinance on living standard was found in Nigerian context by Imoisi \& Opara (20I4).

Kenduiwa \& Jahfer (2016) investigated the influence of smallholder dairy farmers' participation in microfinance on breed improvement in dairy farming in Longisa Sub-Country, Bomet Country, Kenya.Using ordered logistic regression this study revealed that the amount of microfinance credit accessed influenced the type of breeds kept by smallholder dairy farmers. Dairy breeds kept could be attributed to the amount of MFI's credit accessed. The most common type of dairy cattle breed in the study area was indigenous cattle. Smallholder dairy farmers should take advantage of the available and upcoming microfinance institutions in their effort to obtain the necessary finances for breed improvement.

Taj et al., (2012) found that micro credit significantly increased livestock population in agriculturally landless and land owning families. The special emphasis of the study was on the women livestock raisers. The study revealed the impact of institutional credit in terms of women empowerment, improved households' income and consumption.

Boney Bose (2017) investigated the effect of microfinance on dairy sector for poverty alleviation in Kerala. This study indicates that micro finance has made rapid changes for the beneficiaries of dairy sector and it has improved their standard of living. Although the dynamics underlying the micro finance industry have shifted to a new phenomenon that many decision makers still do not fully understand, the risks need to be managed efficiently in the industry of micro finance. The members working under micro finance are able to lead a better life compared to when they were before. They are able to provide better facilities for their family and also provide better education to their children. The next decade will most probably see a continuation of this growth. Such growth is not only sought by many MFIs but also needed in most countries because the unnerved and underserved markets continue to remain large. There should be also good support from government side. Further schemes should be introduced to support the dairy farmers, proper market and training programmes should be given for them. Proper awareness also should be given for dairy farmers to increase production and improve the productivity of milk.

Khandker (1998) conducted a study on income and employment effects of micro-credit programmes in Bangladesh. The article has attempted to quantify the village level impacts of the three most important micro-credit programmes of Bangladesh, namely Grameen Bank, Bangladesh Rural Advancement Committee (BRAC), and Bangladesh Rural Development Board's (BRDB) RD-I2 project. Descriptive and econometric analyses showed that these programmes have 
positive impacts on income, production, and employment, particularly in the rural non-farm sector. Also, growth in selfemployment was achieved at the expense of wage employment, which implied an increase in rural wages.

Khan \& Rahaman (2007) investigated impact of microfinance on living standards, empowerment and poverty alleviation of poor people in the Bangladesh. From analysis of data, the study found that microfinance has a positive impact on the standard of living of the poor people and on their life style. Study further indicated that microfinance has not only helped the poor people to come over the poverty line, but has also helped them to empower themselves in the Bangladesh. Based on the literature review the following hypotheses have been developed in order to conclude the results.

\section{$\mathrm{H}_{\mathrm{I}}$ : There is a significant impact of micro credit on living standard of dairy entrepreneurs}

\section{Conceptual Framework}

The conceptual model which is developed based on the literature review represents the association between micro credit and living standard of dairy entrepreneurs. In this research the main problem is that how micro credit impact on living standard of dairy entrepreneurs. This problem could be conceptualized based on the factors assumed that can cause for this problem.

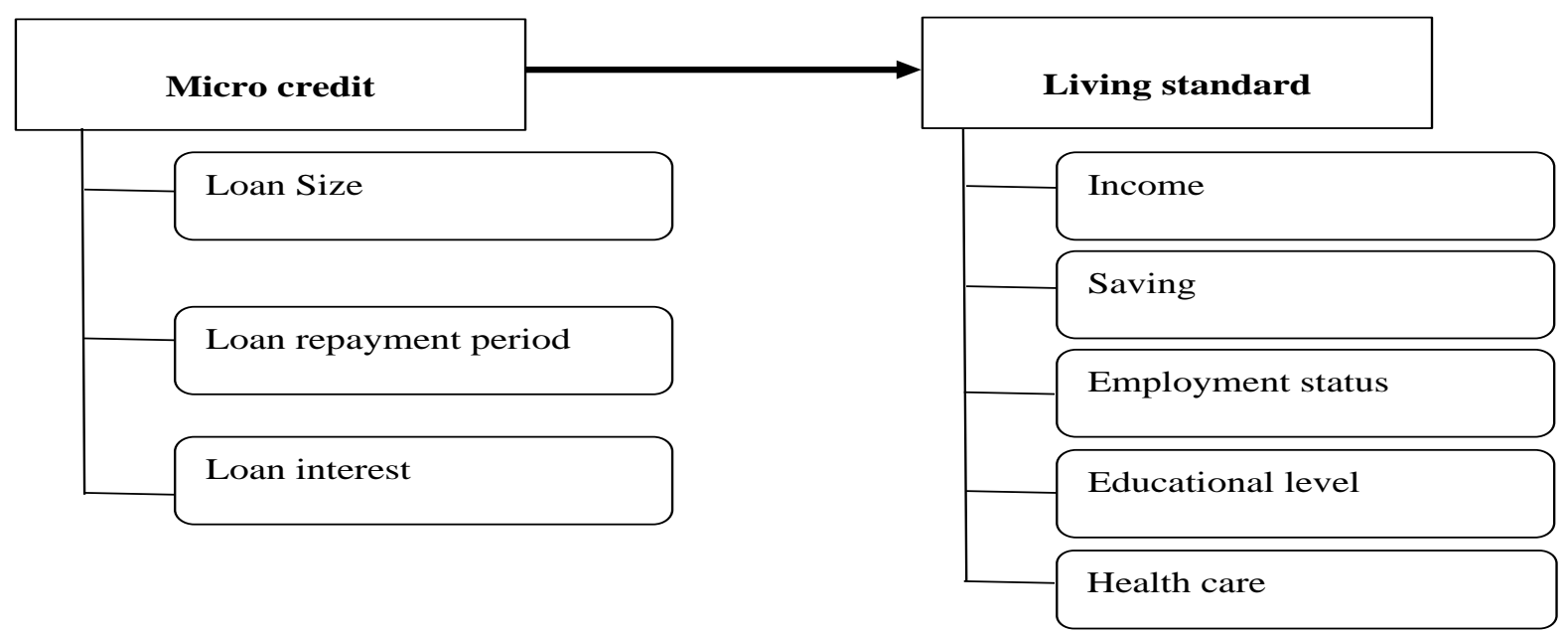

Figure I. Conceptual Model

Micro credit is measured by loan size, loan repayment period and loan interest whereas the living standard considers income, saving, employment status, educational level and health care.

\section{Methodology}

Research methodology focuses on the research process a kind of tools and procedures to be used. It describes research design, sampling procedure, data sources, instrumentation, and mode of analysis

\section{I Data Collection}

Data collection is important stage to gather the required information and maintains the integrity of research. In this study the primary data has been collected by using questionnaire to identify the impact of micro credit on living standard of dairy entrepreneurs in Oddusuddan DS Division. Questionnaires were issued to get the data from selected IOO Samurdhi beneficiaries from 27 Gramaniladhari divisions in Oddusuddan Ds division.

\subsection{Population and Sample}

Two-stage random sampling technique is suitable for selecting samples to achieve the research Objective. In the first stage of random sampling, Samurdhi bank had been selected randomly for data collection purpose.In the second stage, the dairy entrepreneurs who live in the Oddusuddan Ds divisions were selected. Mullaitivu district consist of 6 divisional secretariat division, I36 Gramaniladhari divisions and 632 villages. The population of this study is 257 dairy entrepreneurs and the information has been collected from 100 respondents who were selected randomly.

\subsection{Empirical Model}

To determine the impact of micro credit on living standard, an empirical model was used and stated as follows:

$$
Y=\beta_{0}+\beta_{1} X_{I}+\beta_{2} X_{2}+\beta_{3} X_{3}+\varepsilon
$$


Where,

$\beta_{0}, \beta_{1}, \beta_{2}, \beta_{3}$ are the regression coefficient

$\mathrm{Y}$ - Living standard (dependent variable)

$\mathrm{X}_{\mathrm{I}}$ - Loan size

$\mathrm{X}_{2}$ - Repayment period

$\mathrm{X}_{3} \quad$ - Interest rate

$\mathcal{E}$ - Error term

\section{Results and Discussion}

\section{I Correlation Analysis}

The Pearson correlation coefficient is presented to illustrate the relationship as well as the statistically significant between independent variables and dependent variables. In addition, Pearson's correlation analysis method is chosen because the correlation can be compared without regarding to the amount of variation exhibited by each variable separately. Purpose of the correlation analysis in this study is to find out the significant relationship between micro credit and living standard.

Table I. Correlations between micro credit and living standard

\begin{tabular}{|c|c|c|c|}
\hline & & $\begin{array}{l}\text { Living } \\
\text { Standard }\end{array}$ & Micro Credit \\
\hline \multirow[t]{3}{*}{ Living standard } & Pearson Correlation & $\mathrm{I}$ & $.715^{4 s}$ \\
\hline & Sig. (2-tailed) & & .000 \\
\hline & $\mathrm{N}$ & 100 & 100 \\
\hline \multirow[t]{3}{*}{ Micro credit } & Pearson Correlation & $.715^{\text {sta }}$ & $\mathrm{I}$ \\
\hline & Sig. (2-tailed) & .000 & \\
\hline & $\mathrm{N}$ & 100 & 100 \\
\hline
\end{tabular}

Source: Survey data 2019

Table I represents the correlation coefficient between micro credit and living standard of dairy entrepreneurs in Oddusuddan DS division. The value of correlation between micro credit and living standard is 0.7 I $5(p=0.000<0.0 \mathrm{I})$ which represents a significant and positive association between microcredit and living standard at 0.0I levels. Therefore, microcredit is strongly positive associated with living standard of dairy entrepreneurs.

\subsection{Regression Analysis}

Regression analysis which is a statistical process used to examine the impact of independent variable on dependent variable. In this study regression analysis is employed to examine impact of micro credit on living standard of dairy entrepreneur in Oddusuddan DS division. The results of the regression analysis are given below.

Table 2. Regression Analysis

\begin{tabular}{|c|c|c|c|c|c|c|}
\hline \multicolumn{7}{|c|}{ Coefficients $^{\mathrm{a}}$} \\
\hline \multirow{2}{*}{\multicolumn{2}{|c|}{ Model }} & Unstandardi & Coefficients & Standardized & $\mathrm{t}$ & Sig. \\
\hline & & B & Std. Error & Beta & & \\
\hline \multirow[t]{2}{*}{ I } & (Constant) & 2.363 & 5.743 & & $.4 \mathrm{II}$ & .682 \\
\hline & $\begin{array}{l}\text { Micro } \\
\text { credit }\end{array}$ & 1.783 & .176 & .715 & I0.130 & .000 \\
\hline & $\mathrm{R}=0.7 \mathrm{I5}$ & Adjusted R Sq & $=0.507$ & $\mathrm{~F}=102.610$ & Sig $=.000^{b}$ & \\
\hline
\end{tabular}

Source: Survey data 2019

The above table 2 indicates that the summary of coefficient of regression between the micro credit and living standard. The coefficient of regression ( $\beta$ ) I.783 for micro credit which indicates if micro credit increased by I or I\% then Living standard also will increase by I.783. The P- value for two tailed test is 0.000 , which is less than 0.0I significant levels therefore there is a significant positive impact of micro credit on living standard of dairy entrepreneurs. 


\section{Conclusion and Recommendation}

The results demonstrate that the Samurdhi micro credit plays an important role on reducing poverty, improving income of household, improves access to children's education and also supports improving self-employment activities of poor people. It is found that interest free loans could be used as a powerful tool against poverty. Education and training should be provided for micro credit beneficiaries on how to efficiently utilize the funds. Interest charged on micro credit should be reduced. Further management and staff of micro credit institutions must be given the needed training and education to help build and strengthen the skill, competencies and abilities for effective service delivery. Efforts should also be made to reach the poor who are the target of micro credit policies and programs.

Loan products should be of a longer duration to give beneficiaries opportunities to generate future income out of the borrowed money. Loans should not be callable by the financial institution prior to maturity. Nowadays Samurdhi programme has increased their level of credit for the purpose of beneficiaries.

As the micro credit institutions are developing very rapidly, which are increasingly concerned with developing new products and services. The microcredit institutions have experienced dramatic growth during the last two decades, in general and the last decade, in particular. This study indicates that Samurdhi micro credit has made rapid changes for the beneficiaries of dairy sector and it has improved their standard of living.

The members under the samurdhi credit are able to lead a better life compared to when they were before. They are able to provide better facilities for their family and also provide better education to their children. There should be also good support from government side. Further schemes should be introduced to support the dairy farmers, proper market and training programmes should be given for them. Proper awareness also should be given for dairy farmers to increase production and improve their living standard.

\section{References}

Ahlin, C., \& Jiang, N. (2008). Can micro-credit bring development?. Journal of Development Economics, 86( I), I-2I.

Awele Oguejiofor, D. P. A., \& Unachukwu, U. (20I4). Achieving Poverty Reduction Through Microfinance: Evidences From the Philippines.

Barr, S. (2005). Microfinance and Financial Development. Michigan Journal of International Law, 26, 27I.

Bose, B. (2017). The impact of microfinance on employees of dairy sector: A study in Kottayam District, Kerala. International Journal of advanced Scientific Research \& Development. 4(3),0I-I0.

Idowu, A., \& Salami, A. O. (20II). Impact of microfinance bank on standard of living of hairdresser in Ogbomoso North local government of Oyo State, Nigeria. American joumal of social and management sciences, 2(I), 34-40.

Imoisi, A. I., \& Opara, G. I. (20I4). Microfinance and Its Impact on Poverty Allevation: A case Study of Some Micfrofinance Banks in Edo State Nigeria. American Journal of Humanities and Social Sciences, 2(I), 27-4I.

Jayasuriya, P. K. (2007). Impact of the Micro Finance on Poverty Alleviation in Sri Lanka: Special Reference to Sammurdhi Programme.

Kaluarachchi, D. G. P., \& Jahfer, A. (2014). Micro finance and poverty alleviation in Sri Lanka.

Kenduiwa, A., Mwonya. R., \& Kinuthia, L. (2016). Influence of Smallholder Dairy Farmers' Participation in Microfinance on Breed Improvement in Dairy Farming in Longisa Sub-County, Bomet County, Kenya. Journal of Agriculture and Veterinary Science, 9(7), 66-75.

Khan, M. A., \& Rahaman, M. A. (2007). Impact of microfinance on living standards, empowerment and poverty alleviation of poor people: a case study on microfinance in the Chittagong District of Bangladesh.

Khandker, S. R. (1998). Fighting poverty with microcredit: experience in Bangladesh. Oxford University Press.

Makunyi, D. G. (2017). Impact of Micro Finance Institutions On Poverty Eradication In Meru South Sub-County, Kenya. American Journal of Finance, I(5), I4-30.

Taj, S., Bashir, A., Shahid, R., \& Shah, H. (2012). Livestock development through micro-credit. A hope for poor resource women in rural areas of Faisalabad, Punjab. Journal of Agricultural Research, 50(I), I35-I43.

Thilepan, M., \& Thiruchelvam, S. (20II).Microfinance and livelihood development in poor coastal communities in Eastern Sri Lanka.

\section{Copyrights}

Copyright for this article is retained by the author(s), with first publication rights granted to the journal. This is an openaccess article distributed under the terms and conditions of the Creative Commons Attribution license (http://creativecommons.org/licenses/by/4.0/). 